\section{KÖNNYEBB ÉPÍTKEZÉS - NAGYOBB TERVEZŐI FELELŐSSÉG EGYSZERŰ BEJELENTÉSHEZ KÖTÖTT ÉPÍTÉSI TEVÉKENYSÉG ÉS A KÖTELEZŐ FELELŐSSÉGBIZTOSÍTÁS}

Dr. Szolyka Lilla (vállalati kockázatvállalási teamvezetó, Generali Biztositó Zrt., a MABISZ Felelósségbiztositási Bizottságának elnöke)

\section{ÖSSZEFOGLALÓ}

2016. január 1-jétől - a családi házak építésének támogatása jegyében - megszüntette a jogalkotó az építési hatósági engedélyezési eljárást ebben az építési szegmensben, így a legfeljebb $300 \mathrm{~m}^{2}$ összes hasznos alapterületủ lakóépületek a hatóságnak történő egyszerű bejelentéssel építhetők. A hatósági kontroll megszűnésével párhuzamosan e lakóépületek tervezőire fokozott felelősség hárul, melyet a jogalkotó kötelező felelősségbiztositás előírásával kívánt kompenzálni. A tanulmány a tervezői felelősség változását járja körül, és a felelősségbiztositás főbb sarokpontjait mutatja be.

\section{SUMMARY}

From 1st January 2016 the licencing procedure of construction of private houses has been abolished, therefore house-building up to $300 \mathrm{sqm}$ useful floor-space is subject to simple notification to competent authority. In line with the termination of the preliminary authority control, the architects of the houses bear greater professional liability, which supposed to be covered by compulsory liability insurance prescribed by law. This article presents the changes of the architect's liability and the most important things to know about the liability insurance.

Kulcsszavak: tervezői felelősség, felelősségbiztosítás Keywords: architect's liabitity, liability insurance

JEL: G22, K13

DOI: $10.18530 / B K .2018 .2 .40$

http://dx.doi.org/1018530/BK.2018.2.40

\section{Hatósági engedélyezés helyett egyszerü bejelentés}

Az építési, építészeti tevékenységgel kapcsolatos jogalkotás terén az elmúlt időszakban több változásnak lehettünk tanúi. E változások egyik szelete az „egyszerű bejelentéshez kötött építési tevékenység” bevezetése volt.

2016. január 1. előtt még viszonylag bonyolult hatósági engedélyezési eljáráson kellett átesnie annak, aki családi ház építésére vállalkozott. Az építési hatóság az építtető által benyújtott tervdokumentációt megvizsgálta, hogy a beadott tervek megfelelnek-e az országos (OTÉK - Országos Településrendezési és Építési Követelmények) és helyi (HÉSZ - Helyi Építési Szabályzat) építési szabályoknak. Amennyiben az építkezéshez szakhatósági (pl. műemlékvédelmi, környezetvédelmi, tűzvédelmi, ÁNTSZ stb.) engedélyekre volt szükség, akkor ezeket az építésügyi hatóság beszerezte. A helyi szabályozástól függően gyakran a helyi tervtanács véleményét is ki kellett kérni annak érdekében, hogy a tervezett épület harmonikusan és esztétikusan illeszkedjen a meglévő településszerkezetbe és településképbe. Végül, de nem utolsósorban a hatósági eljárásból a leendő épület szomszédai sem maradtak ki. Amennyiben a tervezett építkezés a telekszomszéd méltányolható jogát vagy jogos érdekét érintette (pl. ingatlanát jelentős mértékben beárnyékolta a leendő épület), abban az esetben az építésügyi hatóság a szomszédot ügyfélként bevonta, és ezzel fellebbezési lehetőséget biztosított neki az építési engedéllyel szemben.

A bürokráciacsökkentés jegyében - 2016. január 1-jétől - a jogalkotó eltörölte a hatósági engedélyezési eljárást a családi házas építkezések esetében. Az építési törvény ${ }^{1}$ ezen hatállyal történő módosítását követően a legfeljebb $300 \mathrm{~m}^{2}$ összes hasznos alapterületủ új lakóépület építése esetén az építtetőnek nem kell építési engedélyt kérnie, hanem elegendő az építési tevékenységet - a kivitelezés tervezett megkezdése előtt 15 nappal - bejelenteni az építésügyi hatóságnak. ${ }^{2} \mathrm{Az}$ eredeti szabályozás szerint a bejelentéshez egy bejelentési nyomtatványt kellett kitölteni, csatolva a jogszabályban meghatározott tartalmú, egyszerű bejelentési dokumentációt.

A lakóépület építésének egyszerű bejelentéséről szóló 155/2016 (VI.13.) számú Kormányrendelet aztán még tovább egyszerüsítette az egyszerü bejelentés módját. 2016. július 1-jétől már nem kell külön kitölteni egy bejelentési nyomtatványt, hanem „az egyszerü bejelentéshez kötött építési tevékenység bejelentése az elektronikus építési napló készenlétbe helyezésével valósul meg”. A készenlétbe helyezés feltétele a kormányrendeletben meghatározott munkarészekből álló kivitelezési dokumentáció feltöltése. Az építtető az építési tevékenységet a bejelentést követő 15 nap elteltét követően megkezdheti.

Néhány hónap elteltével a jogalkotó tovább tágította az egyszerű bejelentéssel végezhető építési tevékenységek körét. ${ }^{3}$ 2017. január 1-jétől már nemcsak a $300 \mathrm{~m}^{2}$ összes hasznos 
alapterületű új lakóépület építése, hanem meglévő lakóépület $300 \mathrm{~m}^{2}$-t meg nem haladó méretüre bővítése, a jogszabályban meghatározottak szerinti átalakítása, illetve az ezen építési munkákhoz szükséges tereprendezés, támfalépítés is az egyszerű bejelentésủ építési munkák körébe került. 2017. április 27-től pedig - az eddigi szabályok megtartása mellett - egyszerü bejelentéssel lehet építeni (bővíteni) bármilyen nagyságú lakóépületet, amennyiben természetes személy az építtető, saját lakhatása biztosítása céljából épül az épület, és a lakóépület egy lakásnál többet nem tartalmaz. ${ }^{4}$

\section{Fokozódó tervezői felelősség}

Az egyszerủ bejelentés bevezetése sok szakmai vitát eredményezett az építész szakmában. A legfontosabb kritikai vélemények azzal kapcsolatban fogalmazódtak meg, hogy a hatósági kontroll megszűnésével párhuzamosan a helyi építési szabályok értelmezésével kapcsolatos felelősség teljes egészében az építészekre hárul. A HÉSZ-ek többsége ugyanis még a korábbi időszak szülötte, azaz akkor készültek, amikor még nem volt egyszerű bejelentés, amikor még a hatósági engedélyezési eljárás szerves része volt az építéshatósággal történő egyeztetés. Ha a HÉSZ hiányos volt, vagy szabályai nem voltak egyértelműek, akkor a hatósági eljárás keretében az építész egyeztethetett az építésügyi hatóság ügyintézőjével. Továbbá ha az építész nem a HÉSZ-nek megfelelően tervezte az épületet, akkor a hatóság hiánypótlást adott ki, vagy elutasította az építési engedélyt. Amennyiben viszont rákerült az építésügyi hatóság pecsétje a tervekre, akkor a tervező joggal bízhatott abban, hogy tervei a helyi és országos építési szabályoknak megfelelnek, tehát - a tervek építési szabályokba ütköző volta miatt - már biztos nem fogják az építtetőt sem megbírságolni, sem az elkészült épületet visszabontatni.

\section{A hatósági kontroll megszúnésével párhuzamosan a helyi építési szabályok értelmezésével kapcsolatos felelösség teljes egészében az építészekre hárul.}

És mi a helyzet jelenleg? Hatósági engedélyezési eljárás híján a tervezők igyekeznek informálisan egyeztetni az építésügyi hatósággal. Mivel azonban az egyszerü bejelentés nem hatósági eljárás, az építésügyi hatóságok nem adhatnak ki hivatalos állásfoglalást. Pláne úgy nem, hogy az egyszerü bejelentés körébe tartozó építkezések esetén a hatósági feladatok az építésfelügyeletekhez kerültek. Az építésfelügyeleteket viszont anno nem arra hozták létre, hogy jogszabályi előírásokat értelmezzenek, és a tervezőket segítsék eligazodni a havi szinten változó helyi és országos építési szabályok dzsungelében, hanem arra, hogy ellenőrizzék a kivitelezést és a kivitelezési munkában részt vevőket.
Sajnos kevés az olyan település, mint például Budaörs, ahol észlelve az egyszerü bejelentéssel várható - tervezőket, építtetőket, várost érintő - anomáliákat, nemcsak lehetővé, hanem egyenesen kötelezővé tették a tervdokumentációval kapcsolatos szakmai konzultációt az építkezés kezdete előtt az építésügyi hatósággal. ${ }^{5}$

A hiányos és nehezen értelmezhető HÉSZ-ek és a gyakran módosuló építési szabályok miatt pedig nagyon könnyű a tervezőknek hibázni, szabályokba ütközően tervezni. A hibák viszont sajnos most túl későn derülnek ki! Akkor, amikor már áll az épület, és például az oldalkert nem megfelelő mérete miatt csak visszabontás vagy az építtetöre kiszabott bírság kerülhet szóba, mellyel kapcsolatos költségek kártérítésként csapódnak vissza az építészekre.

A problémákat tovább fokozza, hogy az építéssel érintett ingatlan telekszomszédai is csak akkor értesülnek az érdekeiket esetlegesen sértő tervekről, amikor az építkezés már megkezdődött. Korábban az építési hatósági eljárásban még tudták érdekeiket érvényesíteni, jelenleg azonban - engedélyezési eljárás híján - csak a bírósági eljárás és a kártérítési igény marad számukra a járható út. Az ezzel kapcsolatos felelősség pedig ismét a tervezőket terhelheti.

Összegezve a fentieket, elmondható, hogy azépítési engedélyezési eljárás hosszú, bürokratikusnak tűnő folyamat volt, viszont biztosította azt, hogy még a megvalósítani kívánt építési tevékenység megkezdése előtt elejét vegyék a jogsértések bekövetkezésének. Miután ugyanis az épület elkészült, már jóval nehezebb és nagyságrendekkel költségesebb a bekövetkezett jogsértéseket orvosolni.

\section{Kötelező felelősségbiztosítás}

Az építési tevékenységet illetően már régóta napirenden volt egy kötelező felelősségbiztosítás bevezetése valamilyen formában. Az építési törvény már 2013. január 1-je óta tartalmaz egy felhatalmazó rendelkezést ${ }^{6}$ egy kormányrendelet létrehozására, amely az építési kivitelezési tevékenységet végző vállalkozások számára kötelezővé teszi a felelősségbiztosítást. Végül azután a kötelező felelősségbiztosítás - 2017. január 1-jei hatállyal - az egyszerű bejelentéshez kötött építési tevékenységhez kapcsolódóan került bevezetésre, mind a kivitelezőket, mind a tervezőket érintően.

Annak ellenére, hogy a kötelező felelősségbiztositás több szakma esetében a szakmagyakorlás feltétele (pl. egészségügyi szolgáltatók, ügyvédek, önálló bírósági végrehajtók, vagyonvédelmi vállalkozások, közjegyzők, biztosítási alkuszok stb.), a tervezők számára előírt felelősségbiztosítást a szakma komoly fenntartásokkal fogadta. Egyrészt bizonyítottnak láták azon aggodalmukat, hogy a hatósági kontroll hiánya miatti felelősség az ő vállukat nyomja majd, amit a jogalkotó felelősségbiztosítási védelemmel kíván kompenzálni. Másrészt tartottak attól, hogy a felelősségbiztosítás díja olyan mértékű lesz, amit majd nem tudnak a tervezői díjakban érvényesíteni, így az eddigi problémák mellett még anyagi terhet is vállalniuk kell. Ezzel kapcsolatban azonban kedvezően alakult a helyzet. A kötelező felelősségbiztosítás bevezetését követően ugyanis 10 biztosító 7 jelent 
meg ilyen termékkel, ami a szakmai felelősségbiztosítások piacán nagyon magasnak mondható. Így a biztosítók versenye igen kedvező díjszintet eredményezett a tervezők számára.

Fontos tehát hangsúlyozni, hogy az építési tevékenységhez kapcsolódóan kizárólag az egyszerü bejelentéssel épülő lakóépületek esetén kötelező felelösségbiztosítást kötni. Tehát azok a tervezök, kivitelezők, akik ezen körön kívül végzik a tevékenységüket (pl. többlakásos lakóházakat, irodaházakat, szállodákat terveznek vagy kiviteleznek), mentesülnek a kötelezettség alól. Azaz csak látszólag mentesülnek, ugyanis az ilyen volumenű beruházások esetén a megrendelők részéről természetes elvárás egy anyagi védelmet nyújtó felelősségbiztosítás megléte. Ennek megfelelően álláspontom szerint feleslegesen túlbonyolított megoldás született a jogalkotó részéről, hiszen ahol nem jogszabályi kötelezettség, ott piaci igény a felelősségbiztosítási fedezet léte. Egyszerűbb és hatékonyabb lett volna - a korábban már említett szakmákhoz hasonlóan - a szakmagyakorlás feltételeként elöírni a kötelező felelősségbiztosítást, függetlenül attól, hogy egyszerű bejelentéssel vagy hatósági engedélyezési eljárás keretében történik-e az építés.

Továbbá nem kell az összes tervezőnek, kivitelezőnek felelősségbiztosítást kötnie, akik egyszerü bejelentéssel érintett épületen dolgoznak! A jogszabály szerint kizárólag az építtetővel közvetlen szerződéses kapcsolatban álló tervezőnek és fővállalkozó kivitelezőnek kell biztosítást kötnie, tehát az alvállalkozóknak nem. ${ }^{8}$ Viszont az építtetővel szerződő tervező és kivitelező felelösségbiztositásának alvállalkozói kiterjesztést kell tartalmaznia, azaz fedezetet kell nyújtania az alvállalkozója által okozott olyan károkra, amelyekért a tervező és a fővállalkozó kivitelező felel.

Fontos szabály még, hogy a tervezői felelősségbiztosításnak fedezetet kell nyúitania nemcsak a tervezéssel, hanem a tervező (vagy azáltala bármilyen jogviszonyban foglalkoztatott másik tervező) által végzett tervezői müvezetésre. Itt kell megjegyeznem, hogy az egyszerü bejelentéssel történő építési tevékenység esetén a tervezői művezetés különös hangsúlyt kapott. A jogszabály szerint ugyanis ebben a körben a tervezői művezetés kötelezö, a tervezőnek (vagy egy általa megbízott másik tervezőnek) legalább hat alkalommal meg kell jelennie az építési helyszínen, a tervet magyaráznia, a felmerülő kérdésekre pedig válaszolnia kell.

Ahogy a tervező felelősségbiztosításának a tervezői művezetésre, úgy a fővállalkozó kivitelező felelösségbiztosításának az általa bármilyen jogviszonyban foglalkoztatott felelős müszaki vezetőre kell kiterjednie. ${ }^{10}$ (A felelős műszaki vezető a kivitelező megbízásából irányítja és ellenőrzi az építési-szerelési munkákat az építési munkaterületen.)

A jogszabály szerint a felelősségbiztositásnak a tervezői, illetve kivitelezői tevékenységgel okozott dologi és személyi sérüléses károkra kell fedezetet nyúitania. ${ }^{11} \mathrm{~A}$ dologi és a személyi sérüléses kár a felelősségbiztosítási fedezetekben alapfogalmak. Személyi sérüléses kár az, ha valaki meghal, testi sérülést vagy egészségkárosodást szenved. Azaz ha például a családi ház lépcsőjének rossz méretezése miatt az építtető leesik a lépcsőn, és eltöri a lábát, akkor a tervező szakmai hibája folytán az építtetőt személyi sérüléses kár érte. Dologi kárnak pedig az tekinthető, ha valamilyen tárgy megsemmisül, megsérül vagy használhatatlanná válik. Így dologi kár lehet például, ha a statikus tervező a talajmechanikai szakvéleményben megkövetelt lemezalap helyett sávalapot tervezett, és ennek következtében az épület fala megrepedt, vagy talajvíznyomás elleni szigeteléshez nem megfelelő anyagot írt elő, és ezért az átnevesedett fal ledobta a vakolatot. A jogszabály az ilyen típusú károk fedezetbe vonását írta elő kötelező jelleggel.

Vannak biztosítások, melyek a jogszabályi minimumelvárásnak megfelelve, kizárólag személyi sérüléses és dologi károkat fedeznek, ugyanakkor vannak olyan biztosítások is, melyek ennél szélesebb biztosítási védelmet kínálnak, és a tisztán pénzügyi jellegü károkat is térítik.

Amennyiben azonban a tervező a helyi építési szabályok helytelen értelmezése miatt például az oldalkertet kisebbre tervezi, vagy az épület homlokzata lesz magasabb az elöírtnál, és az épitésfelügyelet az építtetőt megbírságolja, abban az esetben a megrendelőt egy olyan tisztán pénzügyi veszteség éri, mely sem személyi sérülésnek, sem dologi kárnak nem tekinthető. A hatósági kontroll hiánya miatt pedig éppen az ilyen jellegű károktól tartanak a tervezők! A biztosítási piacon kínált felelősségbiztosítási termékek ebből a szempontból változatos képet mutatnak. Vannak, melyek a jogszabályi minimumelvárásnak megfelelve, kizárólag személyi sérüléses és dologi károkat fedeznek, ugyanakkor vannak olyan biztosítások is, melyek ennél szélesebb biztosítási védelmet kínálnak, és a tisztán pénzügyi jellegű károkat is térítik. Fontos ezért, hogy a felelősségbiztositási szerződések megkötése előtt a tervezők tájékozódjanak az egyes biztosítók által kínált termékek fedezeti köréről, és ezek ismeretében az általuk igényelt kockázatokra kössenek szerződést.

A felelősségbiztosítási szerződések másik sarkalatos pontja a szerződések tartama és ezzel összefüggésben a biztosítások időbeli hatálya. ${ }^{12}$ A jogszabály szerint a felelősségbiztosítás megköthető határozatlan vagy határozott tartamra, egy konkrét építési projektre. A határozott tartamú biztosítást a tervezőknek legkésőbb a tervezési szerződés megkötésekor kell megkötniük, és az építési főnapló megnyitását követő 2 évig kell fenntartaniuk, a kivitelezőknek a munkaterület átadásától a lakóépület teljes műszaki átadás-átvételének lezárásáig kell biztositással rendelkezniük. A biztosítási szerződésnek a jogszabály alapján a biztosítás hatálya alatt okozott és a szerződés megszünését követő 3 éven belül bejelentett károkra kell fedezetet nyújtania. A határozott tartamú biztosítási szerződések általában körülbelül 3 éves időtartamra kötődnek. Ha egy tervezői hiba miatt az épületben keletkezett kár csak évekkel később (pl. 7 év múlva) jelentkezik (azért, mert elhúzódik az építkezés, vagy egyszerüen a hiba jellege miatt), abban az esetben előállhat az a helyzet, hogy a biztosítási szerződés nem fog fedezetet nyújtani a káreseményre. Hiszen a biztosítást a tervezési szerződés megkötésétől számított 3 évre kötötték, és a kár bejelentésére nyitva álló további 3 éves utófedezeti időszak is letelt. Egy határozatlan tartamra megkötött szerződésnél nem állhat elő ez a helyzet, ugyanis a folyamatosan hatályban lévő szerződés akár még egy évtizeddel később megjelenő hibára is fedezetet nyújt. Ezen előny mellett még a kedvezőbb biztosítási díj 
is a határozatlan tartamú szerződések mellett szól. Általánosságban ugyanis kijelenthető, hogy amennyiben egy tervező, kivitelező évente kettőnél több építési projektet visz, akkor alacsonyabb díjszintet eredményezhet éves szinten egy határozatlan tartamú szerződés.

A felelősségbiztosítások biztosítási összegét ${ }^{13}$ a jogszabály a beruházási költségkerethez igazítja, amit az 1.sz. táblázat mutat be.

1. sz. táblázat: Felelősségbiztosítások elvárt biztosítási összege

\begin{tabular}{|c|c|c|}
\hline Beruházási költségkeret & Tervezö & Kivitelező \\
\hline$\ldots . \rightarrow 50.000 .000 \mathrm{Ft}$ & $\begin{array}{l}2.000 .000 \mathrm{Ft} / \text { kár és } \\
6.000 .000 \mathrm{Ft} / \text { év (tartam) }\end{array}$ & $\begin{array}{l}10.000 .000 \mathrm{Ft} / \text { kár és } \\
30.000 .000 \mathrm{Ft} / \text { év (tartam) }\end{array}$ \\
\hline $50.000 .000 \mathrm{Ft} \rightarrow 100.000 .000 \mathrm{Ft}$ & $\begin{array}{l}5.000 .000 \mathrm{Ft} / \text { kár és } \\
15.000 .000 \mathrm{Ft} / \text { év (tartam) }\end{array}$ & $\begin{array}{l}20.000 .000 \mathrm{Ft} / \text { kár és } \\
60.000 .000 \mathrm{Ft} / \text { év (tartam) }\end{array}$ \\
\hline $100.000 .000 \mathrm{Ft} \rightarrow$ & $\begin{array}{c}10.000 .000 \mathrm{Ft} / \text { kár és } \\
30.000 .000 \mathrm{Ft} / \mathrm{év} \text { (tartam) }\end{array}$ & $\begin{array}{l}30.000 .000 \mathrm{Ft} / \mathrm{ká} \text { és } \\
90.000 .000 \mathrm{Ft} / \mathrm{év} \text { (tartam) }\end{array}$ \\
\hline
\end{tabular}

Forrás: saját szerkesztés

Ahogy a táblázatból is látható, tervezők esetében a biztositási összegek a biztosítókálláspontja szerint alacsony összegben kerültek meghatározásra. A jogalkotó attól tartott ugyanis, hogy a magasabb biztosítási összegekhez kapcsolódó magasabb biztosítási dijak miatt jelentôs ellenállásba ütközne a tervezők részéről a kötelező felelősségbiztosítás bevezetése. A biztosítási szakma már a jogszabály előkészítése során, majd a későbbiekben is jelezte a jogalkotó felé a kártérítési limitekkel kapcsolatos aggályát. Biztositást kötni ugyanis annyit jelent, mint felkészülni egy-egy elöre nem látható, nem tervezett, de nagy kiadással járó eseményre. A felelősségbiztosításoknak az a rendeltetésük, hogy megfelelö, stabil anyagi védelmet nyújtsanak a kiszámíthatatlanul, váratlanul bekövetkező szakmai hibák miatti károkra, kártérítési igényekre. Egy tervezői hiba miatti kártéritési igény, a kártérítési igény elhárításához szükséges jogi költségek (szakértői költségek, perköltségek, ügyvédi díj stb.), illetve egyéb járulékos tételek (pl. késedelmi kamat) olyan költségekkel terhelhetik meg a tervező vállalkozást, melyet csak nagy nehézségek árán vagy egyáltalán nem tud finanszírozni. Amennyiben ugyanis a kártérítési igény jogalapjával vagy mértékével kapcsolatban vita van a felek között, és esetleg bírósági eljárás is indul, a $2.000 .000 \mathrm{Ft} /$ kár biztosítási összeg már a jogi költségekkel kimerülhet. Így mire a per lezárul, és megszületik a jogerős itélet, alig marad fedezet magára a kárigényre.
A biztosítási szakma a MABISZ-on keresztül már több fórumon jelezte a döntéshozók felé, hogy kötelező felelősségbiztosítások előírása esetén általánosságban legalább 10.000.000Ft/kár és 50.000.000 Ft/év biztosítási összeget határozzon meg a jogszabály, hiszen ez a mérték nyújthat megfelelő védelmet mind a biztosítottak, mind a károsultak számára. Többször hangsúlyoztuk, hogy a többszörös biztosítási összeg semmiképpen nem jelenti azt, hogy a biztosítási díj is a többszörösére emelkedik. Sőt! Egy csekélyebb díjemeléssel jelentős biztosításiösszeg-emelést lehet elérni, ami a biztosítási védelem nagysága szempontjából minden érintettnek kedvezőbb.

Összegzésként elmondható, hogy a hatósági kontroll hiánya miatti fokozott tervezői felelősségre megfelelő védelmet nyújthat egy átgondoltan megválasztott felelősségbiztosítás. A magyar biztosítási piacon mind a kártérítési limitek, mind a biztositási fedezetek tekintetében széles választékban elérhetők biztositási termékek, így a tervezők, illetve kivitelező vállalkozások igényeiknek és anyagi lehetőségeiknek megfelelően választhatják ki a számukra legmegfelelőbb felelősségbiztosítást.

\section{HIVATKOZÁSOK}

'Az épitett környezet alakitásáról és védelméről szóló 1997. évi LXXVIII. tv.

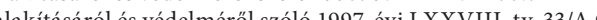

32016. évi CLXXII tv 1.\$S módositotta az 1997. évi LXXVIIL törvényt

${ }^{2}$ Bud ér XXIV. tv. 1.S módositotta az 1997. evi LXXVIII. torvenyl önkormányzati rendelete

“Az épített környezet alakitásáról és védelméról szóló 1997. évi LXXVIII. tv. 39.S (5) bel.

plink=Kotelezo_tervezoi_felelossegbiztositas2

a lakóépület épitésének egyszerủ bejelentéséről szóló 155/2016. (VI.13.) Korm. rendelet 6/A.S (1) bek

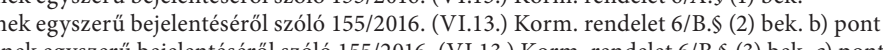
a lakóépület tôsenek egyszerú bejelentéséról szóló 155/2016. (VI.13.) Korm. rendelet 6/B.S (3) bek. c) pont 2a lakóépuület építésének egyszerü bejelentéséśról szoóló 155/2016. (VI.13.) Korm. rendelet 6/A.S (3) bek. és 6/D.\$

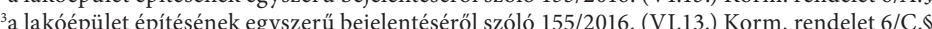

\section{IRODALOMJEGYZÉK}

Az épített környezet alakitásáról és védelmérôl szóló 1997. évi LXXVIII. tv. A lakóépület épitésének egyszerú bejelentéséról szolo 15/2016. VI.13.) Korm. rendele

(IX 21) önkor-

dr. Kugler Zsoltt: Felelősségi kérdések az épitóiparban

https://www.vgfszaklap.hu/lapszamok/2012/julius-augusztus/2459-felelossegi-kerdesek-az-pitoiparban?ml=1

Leẗyszerú bejelelentés csapdái, https://www.epitemahazam.hu/az-egyszeru-bejelentes-csapda/

Épitési engedély versus egyszerü bejelentés, https://www.epitemahazam.hu/epitesi-engedely-versus-egyszeru-bejelentes

Letöltve: 2018.03.10

Korm relet - Az egyszerủ bejelentés is még egyszeróbb lett, https./wwwepitemahazam.hu/az-egyszeru-bejelentes-meg-egyszerubb-le
Letöttre: 2018.03 .10 .

Kooss Miklós: Szeretném megvédeni a HESZ-eket

ES-eket

Koós Miklós: 55753 Etért elmondják neked, hogy miért is ne tervezz laképiletet

http://koos.hu/2018/02/22/43900afaert-elmondjak-neked-hogy-miert-is-ne-tervezz-lakoepuletet/

Letölttve: 2018.03.10.

.

21/a-kotelezo-tervezoi-felelossegbiztositassal-celtablava-valhatnak-az-epiteszek/ 